\title{
Brominated Flame Retardants (BFRS) Analysis in Leachates and Sludge from a Landfill and Wastewater Plant in the Metropolitan Area of Mexico City
}

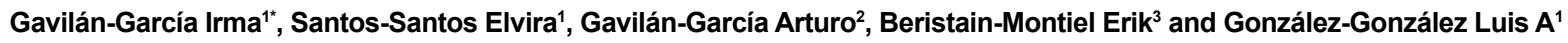 \\ ${ }^{1}$ Environmental Management Unit, Faculty of Chemistry, National Autonomous University of Mexico, Mexico City, Mexico \\ ${ }^{2}$ National Institute of Ecology and Climate Change, Mexico. Periferico Sur 5000. Col. Insurgentes Cuicuilco, Mexico City, Mexico \\ ${ }^{3}$ Atmospheric Sciences Center, National Autonomous University of Mexico, Distrito Federal, 04510. Mexico City, Mexico
}

\begin{abstract}
The biggest landfill in Mexico comprehends an area of 375 hectares and 72 million tons of solid wastes were deposited during 20 years until his closure in December 2012. On the other hand, there is concern of the use of landfill biosolids as feedstock for wastewater treatment plants. Leachate and sludge samples were taken from this landfill and a wastewater treatment plant. Polybrominated Diphenyl Ethers (PBDEs), tetrabromobisphenol A (TBBP-A) and hexabromocyclodecanes (HBCDs) were determined in all samples. This study provides valuable information about BFRs contents and possible release into environment. Results obtained for total PBDEs ranged from not detected (n. d.) to $3.88 \pm 0.38 \mathrm{ng} \mathrm{mL}^{-1}$ in leachates and from n. d. to $23.4 \pm 4.7 \mathrm{ng} \mathrm{g}^{-1}$ in sludges. HBCD was quantified in the range of $0.161 \pm 0.014$ to $0.666 \pm 0.453 \mathrm{ng} \mathrm{mL}^{-1}$ in leachate and from $0.112 \pm 0.042$ to $34.873 \pm 8.262 \mathrm{ng} \mathrm{g}^{-1}$ in sludge samples. TBBP-A, $\beta$-HBCD and BDE-209 were not found in any sample. According to characteristics of the landfill and samples properties, BFRs could proceed from wastes and re-injection of leachates into garbage. Our results suggest the improvement of waste treatment or implementation of remediation procedures.
\end{abstract}

Keywords: Wastewater treatment; Environment; Contaminants; Organic pollutants

\section{Introduction}

Persistent organic pollutants (POPs) are a group of contaminants of world concern because of its relationship to several diseases like endocrine disruption $[1,2]$, reproduction problems $[3,4]$, diabetes $[5,6]$ and cancer [7]. BFRs are intended to be beneficial when used as flameretardant additives in many polymers and resins for the manufacture of electric and electronic (E\&E) products, textile coatings, paints, lacquers, packaging materials, upholstered furniture, and automotive parts; however, recent studies have indicated their adverse effects to the environment for its potential to bioaccumulate [8] and its persistence [9], it has even been found in remote regions, like the arctic, as consequence of the long range transport $[10,11]$. These chemicals are highly toxic [12] especially the lower brominated congeners and decay products.

Frequently, BFRs are released to the environment through waste disposal. In Mexico, the average generation of municipal solid waste (MSW) is $0.86 \mathrm{~kg} \mathrm{day}^{-1}$. This amount is disposed in 400 sanitary landfills and 200 controlled dumps, as well as in hundreds of open dumps. MSW generation in Mexico City is the highest nationwide because of the high population $(8,851,080$ for 2010$)$ [13], which discards around 12,816 ton of MSW per day [14]. 7.613 ton day ${ }^{-1}$ are disposed in five controlled dumps sites located four in the State of México and one in the State of Morelos while the rest is disposed in open dumps around the Mexico City Metropolitan Area (MCMA). Leaching from final dump sites is thought to be a major pathway for BFRs release to the environment [1518]. These are gradually released into the surrounding environment over a period of decade's and causes large amounts of hazardous chemicals to contaminate groundwater, surface water and soil. It also might reach the air, via landfill gas emission [19-21].

Leaching of BFRs results from diffusion driven by the concentration gradient between the leachant and the surface of plastics (Fick's first law). The solid waste composition, particle size, degree of compaction, hydrology, and age of the landfill, moisture, temperature and available oxygen are the controlling factors that determine the rate of production and characteristics of the leachate [22]. In Mexico, there are limited studies of BFRs leaching behavior in landfill sites, such as Bordo Poniente, Santa Catarina and Proactiva. Because recovery of a landfill site takes several decades, long-term studies of the leachability of BFRs from waste and of the fate and transport of BFRs in landfill sites are required.

The objective of this study is to quantify BFRs in leachate and sludge samples taken from one landfill and from a wastewater treatment plant in the metropolitan area of the Mexico City to identify the relevance of this source in the release of POPs to the environment. This study generated the first information related to BFRs contamination in the biggest landfill in Mexico, which is a possible source of high levels of Persistent Organic Pollutants (POPs).

\section{Materials and Methods}

\section{Sampling site}

Bordo Poniente landfill and the wastewater treatment plant selected for this study are located in the MCMA in the State of Mexico as shown in Figure 1.

\section{Chemicals and reagents}

TBBP-A, $\alpha-, \beta-,, \gamma$ - HBCDs, BDEs 17, 28, 49, 71, 47, 66, 100, 99, 85,

*Corresponding author: Gavilán-García Irma, Environmental Management Unit, Faculty of Chemistry, National Autonomous University of Mexico, Av. Universidad 3000, Col. Copilco, Distrito Federal, 04510. Mexico City, Mexico, Tel: 525556223745 ; Fax: 525556223745; E-mail: irmac@unam.mx

Received April 17, 2017; Accepted April 21 , 2017; Published April 25, 2017

Citation: Irma GG, Elvira SS, Arturo GG, Erik BM, Gonzalez-Gonzalez LA (2017) Brominated Flame Retardants (BFRS) Analysis in Leachates and Sludge from a Landfill and Wastewater Plant in the Metropolitan Area of Mexico City. J Environ Anal Toxicol 7: 459. doi: 10.4172/2161-0525.1000459

Copyright: @ 2017 Irma GG, et al. This is an open-access article distributed under the terms of the Creative Commons Attribution License, which permits unrestricted use, distribution, and reproduction in any medium, provided the original author and source are credited. 
Citation: Irma GG, Elvira SS, Arturo GG, Erik BM, Gonzalez-Gonzalez LA (2017) Brominated Flame Retardants (BFRS) Analysis in Leachates and Sludge from a Landfill and Wastewater Plant in the Metropolitan Area of Mexico City. J Environ Anal Toxicol 7: 459. doi: 10.4172/21610525.1000459

Page 2 of 5

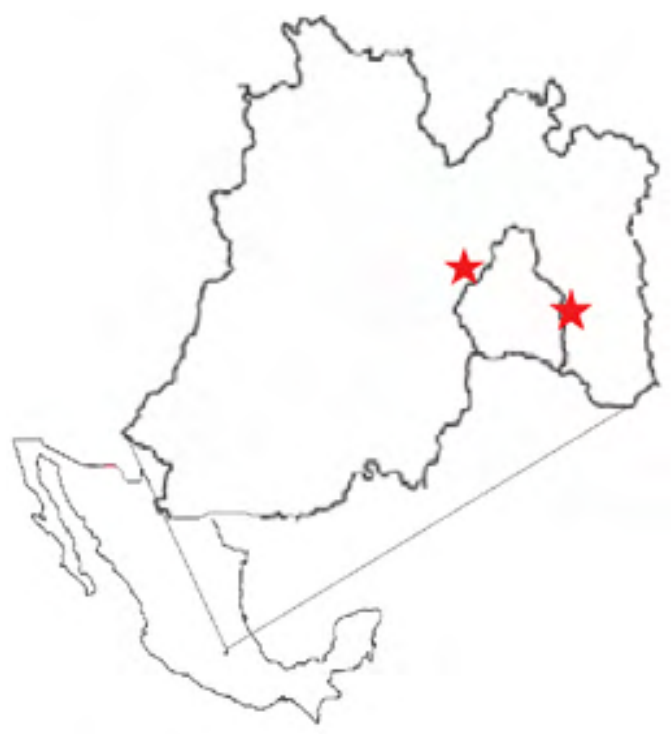

Figure 1: Location of sampling sites in MCMA: Bordo Poniente landfill and wastewater treatment plant.

$154,153,138,183,190$ and 209. solutions in toluene $\left(50 \mu \mathrm{gL}^{-1}\right)$ were acquired from Wellington lab (Guelp, Ontario, CA), as well as internal standards ${ }^{13} \mathrm{C}$-TBBP-A, deuterated $\alpha-, \beta-, \gamma$ - HBCDs and ${ }^{13} \mathrm{C}-\mathrm{BDE}-209$ in toluene $\left(5 \mu \mathrm{g} \mathrm{mL}^{-1}\right)$. Dichloromethane and hexane HPLC grade were purchased to Chromasolv (USA).

\section{Sampling}

Ten sludge and ten leachates samples were collected by duplicate from Bordo Poniente landfill. Also 4 effluents and 5 sludge samples were taken by duplicate from a San Juan Ixhuatepec Wastewater Treatment Plant. All samples were taken by duplicate into $1 \mathrm{~L}$ amber glass flasks, transported at $4^{\circ} \mathrm{C}$ and stored at $4^{\circ} \mathrm{C}$ until extraction procedure.

\section{Extraction procedure}

Leachates were liquid-liquid extracted with $300 \mathrm{~mL}$ dichloromethane using magnetic agitation for 1 hour, then organic phase was filtered through sodium sulfate anhydrous and evaporated until $1 \mathrm{~mL}$ to perform clean-up procedure.

Sludge were dried in a lab hood over aluminum foils and then homogenized with anhydrous sodium sulfate, the mixture was put into glass thimble and soxhlet extracted overnight with dichloromethane reflux. Organic extracts were evaporated until $1 \mathrm{~mL}$ and carried out to clean-up procedure. The $1 \mathrm{~mL}$ final extracts were divided in two fractions. A fraction of $500 \mu \mathrm{L}$ was used for PBDEs analysis with Gas Chromatography - Mass Spectrometry (GC/MS) with addition of 13C-BDE-209 as internal standard and the other $500 \mu \mathrm{L}$ portion was evaporated near to dryness and reconstituted with isopropanol with addition of 13C-TBBP-A and deuterated $\alpha-, \beta$-, and $\gamma$-HBCD isomers for HBCD and TBBP-A analysis with High Resolution Liquid Chromatography - Mass Spectrometry analysis (HPLC/MS).

\section{Clean-up procedure}

$1 \mathrm{~mL}$ extracts were passed through micro silica gel column $(1 \mathrm{~g}$ sodium sulfate to the top and bottom and $5 \mathrm{~g}$ of deactivated silica gel as stationary phase) and eluted with $25 \mathrm{~mL}$ of hexane, then they were evaporated with nitrogen until $1 \mathrm{~mL}$ for instrumental analysis.

\section{Instrumental analysis}

GC/MS analysis. The following PBDEs congeners were analyzed: 17, 28, 49, 71, 47, 66, 100, 99, 85, 154, 153, 138, 183, 190 and 209. 17 PBDEs. A GC/MS (6890- Micromass Auto Spec Ultima MS) with autosampler and single quadrupole was employed. $1 \mu \mathrm{L}$ of extracts were injected in splitless mode at $250^{\circ} \mathrm{C}$. A capillary column DB- $5 \mathrm{~ms} 30 \mathrm{~m}$ length, 0.25 $\mathrm{mm}$ i. d. and $0.10 \mu \mathrm{m}$ thin layer was used. The oven was programmed to $100^{\circ} \mathrm{C}$ for $2 \mathrm{~min}$, first rate $6^{\circ} \mathrm{C} \mathrm{min}{ }^{-1}$ to $250^{\circ} \mathrm{C}$, second rate $25^{\circ} \mathrm{C}$ min ${ }^{1}$ to $300^{\circ} \mathrm{C}$ and kept for $20 \mathrm{~min}$. Helium flux of $1 \mathrm{~mL} \mathrm{~min}^{-1}$ was used as carrier gas and methane as reactive gas. MS in Negative Chemical Ionization mode was used for detection.

HPLC/MS analysis. Instrumental analysis of HBCD and TBBP-A was performed using an Agilent 1200 liquid chromatograph coupled to an AB SCIEX Q-Trap 5500 series mass spectrometer equipped with an electrospray ionization source operated in negative ionization mode. $3 \mu \mathrm{L}$ of each sample were injected into a Zorbax Eclipse C18 column $(2.1 \mathrm{~mm} \times 100 \mathrm{~mm}, 3.5 \mu \mathrm{m})$. The mobile phase was a mixture of water:acetonitrile $(1: 1 \mathrm{v} / \mathrm{v})$ as solvent $\mathrm{A}$, and methanol as solvent $\mathrm{B}$ at a flow of $250 \mathrm{~L} \mathrm{~min}^{-1}$. HPLC gradient program was as follows: solvent $\mathrm{A}$ $60 \%$ to $0 \%$ and solvent $\mathrm{B}$ from $60 \%$ to $100 \%$ in $3 \mathrm{~min}$, maintained for 5 min. Then, solvent B passes from $100 \%$ to $40 \%$ and solvent A from $0 \%$ to $60 \%$ in $3 \mathrm{~min}$. These conditions were maintained during $7 \mathrm{~min}$. For TBBP-A analysis, $3 \mu \mathrm{L}$ of each sample was injected, at a flow of $250 \mathrm{~mL}$ min $^{-1}$. Gradient program was as follows: solvent A $40 \%$ and solvent B from $60 \%$ during $3 \mathrm{~min}$. Then, solvent B passes from $60 \%$ to $100 \%$ and solvent $\mathrm{A}$ from $40 \%$ to $0 \%$ in $4 \mathrm{~min}$. These conditions were maintained during $15 \mathrm{~min}$. Later, solvent A passes from $0 \%$ to $50 \%$ and solvent $B$ from $100 \%$ to $50 \%$ and these conditions were kept for $7 \mathrm{~min}$. Solvent A was water and solvent B a methanolic solution of $0.1 \mathrm{mM}$ ammonium acetate.

The triple quadrupole was operated in selected reaction monitoring mode (SRM): $[\mathrm{M}-\mathrm{H}]^{-} \rightarrow \mathrm{Br}^{-}$. For HBCD transitions monitored were $\mathrm{m} / \mathrm{z}$ $640.6 \rightarrow 78.9$ and $640.6 \rightarrow 80.9$ for native; $652.6 \rightarrow 78.9$ and $652.9 \rightarrow 80.9$ for 18D-HBCDs. For TBBP-A analysis, the monitored transitions were $542.9 \rightarrow 78.9$ and $542.9 \rightarrow 80.9$ (native TBBP-A); $554.9 \rightarrow 78.9$ and 554.9 $\rightarrow 80.9$ (13C-TBBP-A).

\section{Results and Discussion}

Table 1 shows concentrations of BFRs found in the landfill and the wastewater treatment plant. Brominated flame retardants, TBBP-A and $\beta$-HBCD were not found in any sample; this result is congruent with other studies in which TBBP-A was found in low levels and $\beta$-HBCD is the less stable isomer and never had been found in sludge and leachate samples [23-25].

The results obtained show high concentration of $\gamma$-HBCD diasteroisomer in higher concentration than $\alpha-\mathrm{HBCD}$ isomer. This could be due to innate composition of the HBCD commercial mixtures. Normally, the $\gamma$-isomer is the most abundant isomer in the commercial mixture, ranging between 75 and $89 \%$ of total composition, followed by $\alpha$-and $\beta$-isomers with $10-13 \%$ and $1-12 \%$, respectively. On the other hand, sludges had higher levels of HBCDs than leachates (Figures 2 and 3). This may be due to greater lipophilicity of sludges than water on leachates.

PBDEs were found in both leachates and sludge. According to Figures 2 and 3, higher concentrations were found in sludge samples due to organic matter content. Congeners BDE-47 and BDE-99 were more persistent in leachates while compounds BDE-47, -99, -100 and -153 were more abundant in sludge samples. This suggested that PBDEs 
Citation: Irma GG, Elvira SS, Arturo GG, Erik BM, Gonzalez-Gonzalez LA (2017) Brominated Flame Retardants (BFRS) Analysis in Leachates and Sludge from a Landfill and Wastewater Plant in the Metropolitan Area of Mexico City. J Environ Anal Toxicol 7: 459. doi: 10.4172/21610525.1000459

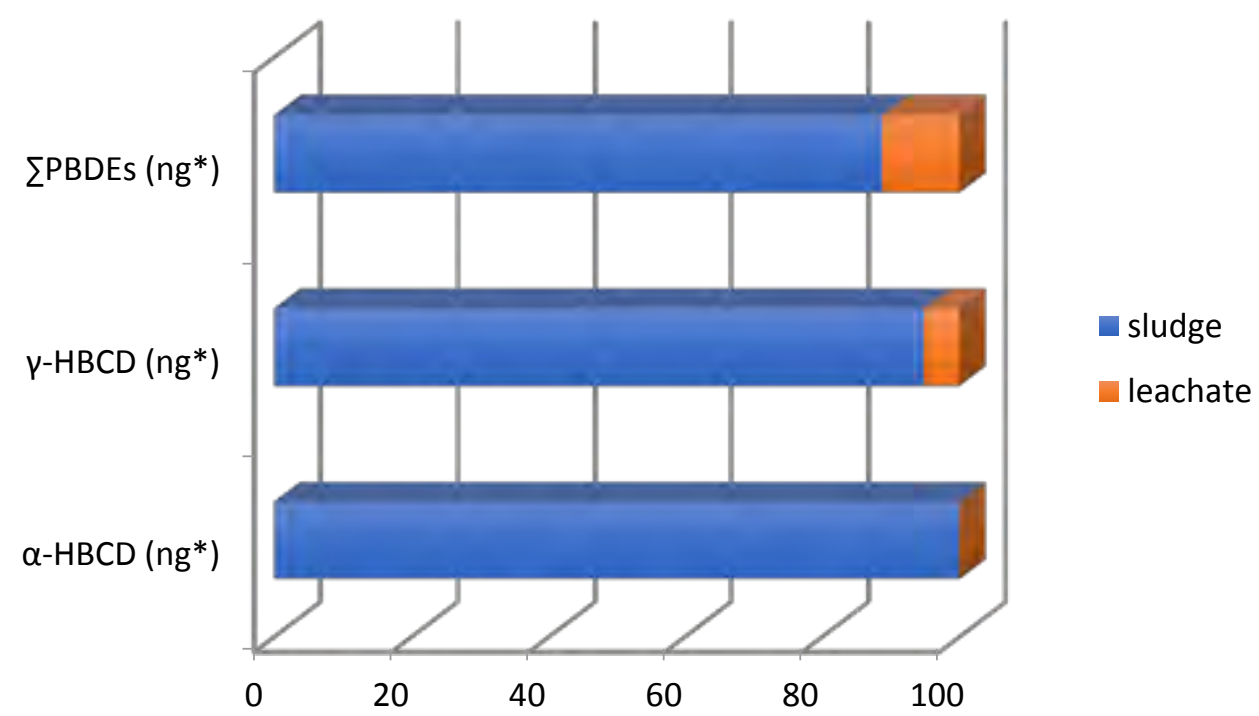

Figure 2: Distribution of Brominated Flame Retardants in leachate and sludge in Bordo Poniente Landfill in percentage.

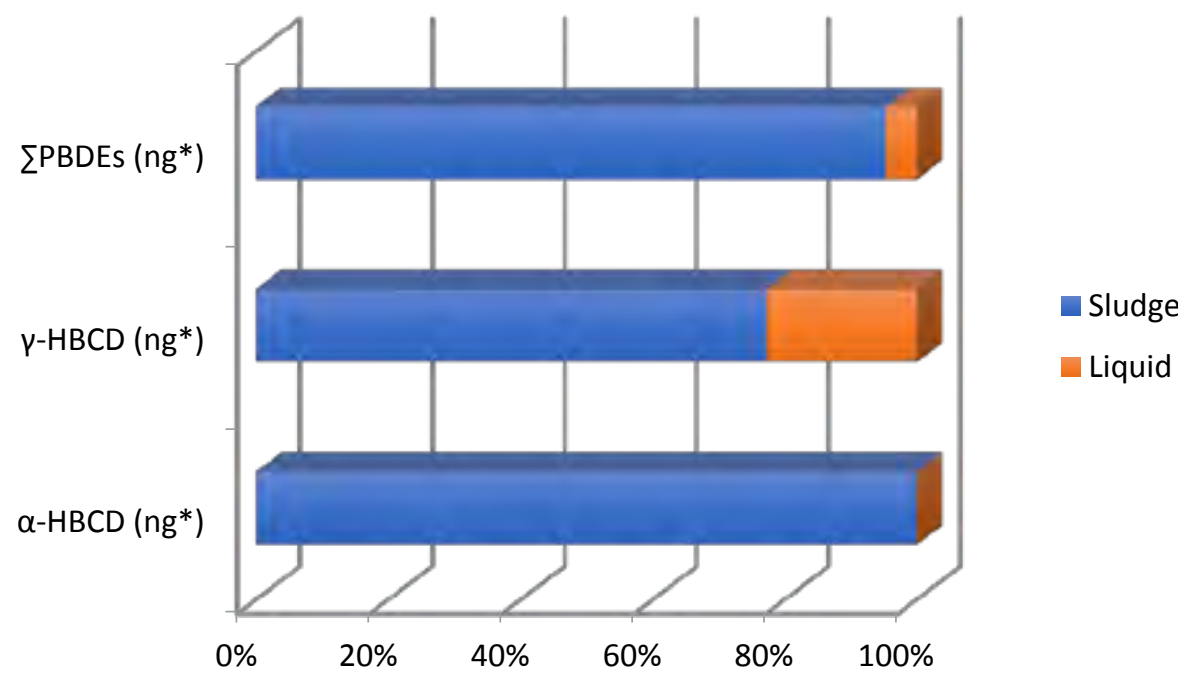

Figure 3: Distribution of Brominated Flame Retardants in liquid and sludge in Wastewater Treatment Plant in percentage.

released from waste into the landfill soil and leachates proceed from pentaBDE and octaBDE commercial mixtures used in end of life products. BDE-209 was not detected in any sample suggesting that products containing this congener could not have been disposed yet. Products which use DecaBDE commercial mixture could still be used in products since decaBDE was the last mixture to have been prohibited [26].

Concentration of PBDEs was higher than HBCD in both samples. Results differ from other studies where BDE-209 and TBBP-A were the most abundant in leachates and biosolids. This results imply that electronic wastes in Mexico might had different composition of BFRs than other countries $[23,24,27]$. The similar concentrations of BFRs between different sampling sites suggest that wastes are homogenous in the landfills. This could be explained because of the continuous reinjection of leachates into the landfill, a common practice in these sites to avoid leachates treatment. Meanwhile, influents samples showed low concentration of PBDEs and in the corresponding effluent samples PBDEs were not detected. This result could indicate that the wastewater treatment plant could remove low concentrations of PBDEs.

BFRs concentrations in this study were lower than other similar studies in other countries [22-25,27-30], however the characteristics of the landfill like the great volume of solid wastes as well as the re injection of leachates into the landfill could contribute to the release and concentration of contaminants in the landfill. 
Citation: Irma GG, Elvira SS, Arturo GG, Erik BM, Gonzalez-Gonzalez LA (2017) Brominated Flame Retardants (BFRS) Analysis in Leachates and Sludge from a Landfill and Wastewater Plant in the Metropolitan Area of Mexico City. J Environ Anal Toxicol 7: 459. doi: 10.4172/21610525.1000459

Page 4 of 5

\begin{tabular}{|c|c|c|c|c|c|}
\hline Site & Sample & Location & $\alpha-H B C D\left(n^{*}\right)$ & Y-HBCD (ng*) & $\sum$ PBDEs $\left(\mathbf{n g}^{*}\right)$ \\
\hline \multirow{10}{*}{ 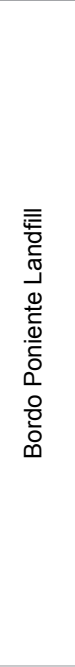 } & $\begin{array}{c}\text { Leachate } 01 \\
\text { Sludge } 01\end{array}$ & $\begin{array}{l}19^{\circ} 27^{\prime} 47.21 " \mathrm{~N} \\
99^{\circ} 0 ' 39.94 " \mathrm{~W}\end{array}$ & $\begin{array}{l}\text { n. d. } \\
\text { n.d. }\end{array}$ & $\begin{array}{l}0.392 \pm 0.068 \\
0.116 \pm 0.006\end{array}$ & $\begin{array}{c}3.88 \pm 0.38 \\
14.42 \pm 3.76\end{array}$ \\
\hline & $\begin{array}{c}\text { Leachate } 02 \\
\text { Sludge } 02\end{array}$ & $\begin{array}{l}19^{\circ} 27^{\prime} 19.40 " \mathrm{~N} \\
99^{\circ} 11^{\prime} 13.15^{\prime \prime} \mathrm{W}\end{array}$ & $\begin{array}{c}\text { n. d. } \\
0.007 \pm 0.009\end{array}$ & $\begin{array}{l}0.666 \pm 0.456 \\
0.123 \pm 0.023\end{array}$ & $\begin{array}{l}0.80 \pm 0.16 \\
3.65 \pm 0.77\end{array}$ \\
\hline & $\begin{array}{l}\text { Leachate } 03 \\
\text { Sludge } 03\end{array}$ & $\begin{array}{l}19^{\circ} 26^{\prime} 52.16 " \mathrm{~N} \\
99^{\circ} 0^{\prime} 29.84^{\prime \prime} \mathrm{W}\end{array}$ & $\begin{array}{c}\text { n. d. } \\
0.078 \pm 0.078\end{array}$ & $\begin{array}{l}0.179 \pm 0.024 \\
0.453 \pm 0.323\end{array}$ & $\begin{array}{c}\text { n. d. } \\
0.79 \pm 0.15\end{array}$ \\
\hline & $\begin{array}{c}\text { Leachate } 04 \\
\text { Sludge } 04\end{array}$ & $\begin{array}{l}19^{\circ} 27^{\prime} 20.75 " \mathrm{~N} \\
99^{\circ} 1 ' 16.03 " \mathrm{~W}\end{array}$ & $\begin{array}{c}\text { n. d. } \\
0.134 \pm 0.068\end{array}$ & $\begin{array}{l}0.197 \pm 0.034 \\
1.366 \pm 0.299\end{array}$ & $\begin{array}{l}0.74 \pm 0.24 \\
4.03 \pm 0.69\end{array}$ \\
\hline & $\begin{array}{l}\text { Leachate } 05 \\
\text { Sludge } 05\end{array}$ & $\begin{array}{l}19^{\circ} 27^{\prime} 50.23^{\prime \prime N} \\
99^{\circ} 0^{\prime} 42.51^{\prime \prime} \mathrm{W}\end{array}$ & $\begin{array}{l}\text { n. d. } \\
\text { n. d. }\end{array}$ & $\begin{array}{l}0.157 \pm 0.007 \\
0.173 \pm 0.019\end{array}$ & $\begin{array}{c}0.58 \pm 0.04 \\
12.07 \pm 1.73\end{array}$ \\
\hline & $\begin{array}{l}\text { Leachate } 06 \\
\text { Sludge } 06\end{array}$ & $\begin{array}{l}19^{\circ} 27^{\prime} 37.80 " \mathrm{~N} \\
99^{\circ} 00^{\prime} 58.18 " \mathrm{~W}\end{array}$ & $\begin{array}{l}\text { n. d. } \\
\text { n. d. }\end{array}$ & $\begin{array}{l}0.148 \pm 0.001 \\
3.577 \pm 2.804\end{array}$ & $\begin{array}{c}2.06 \pm 0.10 \\
16.67 \pm 3.20\end{array}$ \\
\hline & $\begin{array}{l}\text { Leachate } 07 \\
\text { Sludge } 07\end{array}$ & $\begin{array}{l}19^{\circ} 27^{\prime} 30.13^{\prime \prime N} \\
99^{\circ} 0 ' 54.40 " \mathrm{~W}\end{array}$ & $\begin{array}{l}\text { n. d. } \\
\text { n. d. }\end{array}$ & $\begin{array}{c}0.149 \pm 0.001 \\
34.873 \pm 8.262\end{array}$ & $\begin{array}{l}0.52 \pm 0.01 \\
9.88 \pm 1.70\end{array}$ \\
\hline & $\begin{array}{l}\text { Leachate } 08 \\
\text { Sludge } 08\end{array}$ & $\begin{array}{l}19^{\circ} 27^{\prime} 33.81 " \mathrm{~N} \\
99^{\circ} 0^{\prime} 57.83^{\prime \prime} \mathrm{W}\end{array}$ & $\begin{array}{l}\text { n. d. } \\
\text { n. d. }\end{array}$ & $\begin{array}{l}0.149 \pm 0.001 \\
2.271 \pm 2.897\end{array}$ & $\begin{array}{c}0.55 \pm 0.02 \\
17.16 \pm 3.53\end{array}$ \\
\hline & $\begin{array}{l}\text { Leachate } 09 \\
\text { Sludge } 09\end{array}$ & $\begin{array}{l}19^{\circ} 27^{\prime} 36.54 " \mathrm{~N} \\
99^{\circ} 00^{\prime} 59.21 " \mathrm{~W}\end{array}$ & $\begin{array}{c}\text { n. d. } \\
0.064 \pm 0.089\end{array}$ & $\begin{array}{l}0.157 \pm 0.011 \\
0.451 \pm 0.470\end{array}$ & $\begin{array}{l}1.61 \pm 0.33 \\
9.55 \pm 1.49\end{array}$ \\
\hline & $\begin{array}{l}\text { Leachate } 10 \\
\text { Sludge } 10\end{array}$ & $\begin{array}{l}19^{\circ} 27^{\prime} 29.18 " \mathrm{~N} \\
99^{\circ} 0^{\prime} 55.58^{\prime \prime W}\end{array}$ & $\begin{array}{l}\text { n. d. } \\
\text { n. d. }\end{array}$ & $\begin{array}{l}0.156 \pm 0.005 \\
0.535 \pm 0.022\end{array}$ & $\begin{array}{l}1.62 \pm 0.31 \\
9.41 \pm 2.13\end{array}$ \\
\hline \multirow{5}{*}{ 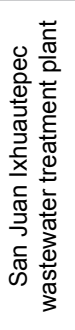 } & $\begin{array}{l}\text { Influent } 01 \\
\text { Sludge } 11\end{array}$ & $\begin{array}{l}19^{\circ} 31 ' 13.70 " \mathrm{~N} \\
99^{\circ} 77^{\prime} 29.08^{\prime \prime W}\end{array}$ & $\begin{array}{c}\text { n. d. } \\
0.086 \pm 0.040\end{array}$ & $\begin{array}{l}0.182 \pm 0.019 \\
0.848 \pm 0.342\end{array}$ & $\begin{array}{c}1.70 \pm 0.10 \\
15.1 \pm 2.4\end{array}$ \\
\hline & $\begin{array}{l}\text { Influent } 02 \\
\text { Sludge } 12\end{array}$ & $\begin{array}{l}19^{\circ} 31^{\prime} 13.19^{\prime \prime} \mathrm{N} \\
99^{\circ} 7{ }^{\prime} 29.40 " \mathrm{~W}\end{array}$ & $\begin{array}{c}\text { n. d. } \\
0.028 \pm 0.039\end{array}$ & $\begin{array}{l}0.162 \pm 0.015 \\
0.275 \pm 0.216\end{array}$ & $\begin{array}{c}2.10 \pm 0.80 \\
13.1 \pm 1.9\end{array}$ \\
\hline & $\begin{array}{l}\text { Effluent } 01 \\
\text { Sludge } 13\end{array}$ & $\begin{array}{l}19^{\circ} 31 ' 13.12 " \mathrm{~N} \\
99^{\circ} 7{ }^{\prime} 28.72 " \mathrm{~W}\end{array}$ & $\begin{array}{c}\text { n. d. } \\
0.526 \pm 0.602\end{array}$ & $\begin{array}{l}0.161 \pm 0.014 \\
0.717 \pm 0.420\end{array}$ & $\begin{array}{c}\text { n. d. } \\
23.4 \pm 4.7\end{array}$ \\
\hline & $\begin{array}{l}\text { Effluent } 02 \\
\text { Sludge } 14\end{array}$ & $\begin{array}{l}19^{\circ} 31^{\prime} 12.49 " \mathrm{~N} \\
99^{\circ} 77^{\prime 2} 29.05^{\prime \prime} \mathrm{W}\end{array}$ & $\begin{array}{c}\text { n. d. } \\
0.020 \pm 0.023\end{array}$ & $\begin{array}{l}0.191 \pm 0.058 \\
0.112 \pm 0.042\end{array}$ & $\begin{array}{c}\text { n. d. } \\
12.2 \pm 2.3\end{array}$ \\
\hline & Sludge 15 & $\begin{array}{l}19^{\circ} 31^{\prime} 12.04 " \mathrm{~N} \\
99^{\circ} 7 ' 28.55 " \mathrm{~W}\end{array}$ & $0.068 \pm 0.019$ & $0.412 \pm 0.203$ & $14.8 \pm 3.3$ \\
\hline
\end{tabular}

Table 1: Concentrations of BFRs founded in the landfill and the wastewater treatment plant.

\section{Conclusions}

PBDEs were determined in higher concentration than $\gamma$-HBCD, while $\beta$-HBCD, TBBP-A, BDEs -28, -154 and -209 were not detected in any sample. According to characteristics of the landfill and samples properties, BFRs could proceed from end of life products and are concentrated because of leachates re-injection into waste piles. Results suggest the improvement of waste treatment or implementation of remediation procedures to eliminate BFR from the waste stream. Regulation has to be enforced in terms of management of leachate from landfills and effluent from wastewater treatment plants. There is also needed to implement regulation on the content of BFRs in products. On this regards, Basel Convention guidelines on low persistent organic pollutants content might be used.

\section{References}

1. Chao HR, Huang HL, Hsu YC, Lin CW, Lin DY, et al. (2014) Impact of brominated POPs on the neurodevelopment and thyroid hormones of young children in an indoor environment-A review. Aerosol Air Qual Res 14: 1320-1332.

2. Huang F, Wen S, Li J, Zhong Y, Zhao Y, et al. (2014) The human body burden of polybrominated diphenyl ethers and their relationships with thyroid hormones in the general population in Northern China. Sci Total Environ 466-467: 609-615.

3. Vested A, Giwercman A, Bonde JP, Toft G (2014) Persistent organic pollutants and male reproductive health. Asian $\mathrm{J}$ Androl 16: 71-80.

4. Hsu P, Guo YL, Smith DR, Linu SY, Tseng L, et al. (2014) Airborne Persistent Organic Pollutants and Male Reproductive Health. Aerosol Air Qual Res 14: 1292-1298.

5. De Tata V (2014) Association of dioxin and other persistent organic pollutants (POPs) with diabetes: epidemiological evidence and new mechanisms of beta cell dysfunction. Int J Mol Sci 15: 7787-7811.

6. Magliano DJ, Loh VH, Harding JL, Botton J, Shaw JE (2014) Persistent organic pollutants and diabetes: a review of the epidemiological evidence. Diabetes Metab 40: 1-14.
7. Hardell L, Bavel B, Lindström G, Eriksson M, Carlberg M (2006) In utero exposure to persistent organic pollutants in relation to testicular cancer risk. Int J Androl 29: 228-234.

8. Mizukawa K, Takada H, Takeuchi I, Ikemoto T, Omori K, et al. (2009) Bioconcentration and biomagnification of polybrominated diphenyl ethers (PBDEs) through lower-trophic-level coastal marine food web. Mar Pollut Bul 58: $1217-1224$.

9. de Wit CA (2002) An overview of brominated flame retardants in the environment. Chemosphere 46: 583-624.

10. Birnbaum LS, Staskal DF (2004) Brominated flame retardants: cause for concern? Environ Health Perspect 112: 9-17.

11. de Wit CA, Herzke D, Vorkamp K (2010) Brominated flame retardants in the Arctic environment--trends and new candidates. Sci Total Environ 408: 2885-2918.

12. Darnerud PO (2003) Toxic effects of brominated flame retardants in man and in wildlife. Environ Int 29: 841-853.

13. Instituto Nacional de Ecología y Cambio Climático, México, 2014.

14. Secretaria del Medio Ambiente, Mexico, 2013.

15. Kwan C, Takada H, Mizukawa K, Torii M, Koike T, et al. (2013) PBDEs in leachates from municipal solid waste dumping sites in tropical Asian countries: phase distribution and debromination. Environ Sci Pollut Res 20: 4188-4204.

16. Weber R, Watson A, Forter M, Oliaei F (2011) Review Article: Persistent organic pollutants and landfills - a review of past experiences and future challenges. Waste Manag Res 29: 107-121

17. Osako M, Kim YJ, Sakai S (2004) Leaching of brominated flame retardants in leachate from landfills in Japan. Chemosphere 57: 1571-1579.

18. Danon-Schaffer MN, Mahecha-Botero A, Grace JR, Ikonomou M (2013) Mass balance evaluation of polybrominated diphenyl ethers in landfill leachate and potential for transfer from e-waste. Sci Total Environ 461-462: 290-301.

19. Odusanya DO, Okonkwo JO, Botha B (2009) Polybrominated diphenyl ethers (PBDEs) in leachates from selected landfill sites in South Africa. Waste Manag 29: 96-102. 
Citation: Irma GG, Elvira SS, Arturo GG, Erik BM, Gonzalez-Gonzalez LA (2017) Brominated Flame Retardants (BFRS) Analysis in Leachates and Sludge from a Landfill and Wastewater Plant in the Metropolitan Area of Mexico City. J Environ Anal Toxicol 7: 459. doi: 10.4172/21610525.1000459

20. Abd El-Salam MM, Abu-Zuid G (2015) Impact of landfill leachate on the groundwater quality: A case study in Egypt. J Adv Res 6: 579-586.

21. Mor S, Ravindra K, Dahiya RP, Chandra A (2006) Leachate Characterization and Assessment of Groundwater Pollution Near Municipal Solid Waste Landfill Site. Environ. Monit. Assess 118: 435-456.

22. Asuma $O$ (2013) Leachate Characterization and Assessment of Groundwater and Surface Water Qualities Near Municipal Solid Waste Dump Site in Effurun, Delta State, Nigeria. Journal of Environment and Earth Science 3: 126-135.

23. Kim M, Guerra P, Alaee M, Smyth SA (2014) Occurrence and fate of four nove brominated flame retardants in wastewater treatment plants. Environ Sci Pollut Res Int 21: 13394-13404.

24. Guerra P, Kim M, Teslic S, Alaee M, Smyth SA (2015) Bisphenol-A removal in various wastewater treatment processes: operational conditions, mass balance, and optimization. J Environ Manage 152: 192-200.

25. Gorga M, Martínez E, Ginebreda A, Eljarrat E, Barceló D (2013) Determination of PBDEs, HBB, PBEB, DBDPE, HBCD, TBBPA and related compounds in sewage sludge from Catalonia (Spain). Sci Total Environ 444: 51-59.
26. Xu W, Wang X, Cai Z (2013) Analytical chemistry of the persistent organic pollutants identified in the Stockholm Convention: A review. Anal Chim Acta 790: $1-13$

27. Kim M, Guerra P, Theocharides M, Barclay K, Smyth SA, et al. (2013) Polybrominated diphenyl ethers in sewage sludge and treated biosolids: Effect factors and mass balance. Water Res 47: 6496-6505.

28. Guerra P, Eljarrat E, Barceló D (2010) Simultaneous determination of hexabromocyclododecane, tetrabromobisphenol A, and related compounds in sewage sludge and sediment samples from Ebro River basin (Spain). Anal. Bioanal. Chem 397: 2817-2824.

29. Ricklund N, Kierkegaard A, McLachlan MS, Wahlberg C (2009) Mass balance of decabromodiphenyl ethane and decabromodiphenyl ether in a WWTP. Chemosphere 74: 389-394.

30. Eljarrat E, De La Cal A, Barceló D (2004) Determination of decabromodiphenyl ether in sediments using selective pressurized liquid extraction followed by GCNCl-MS. Anal Bioanal Chem 378: 610-614. 